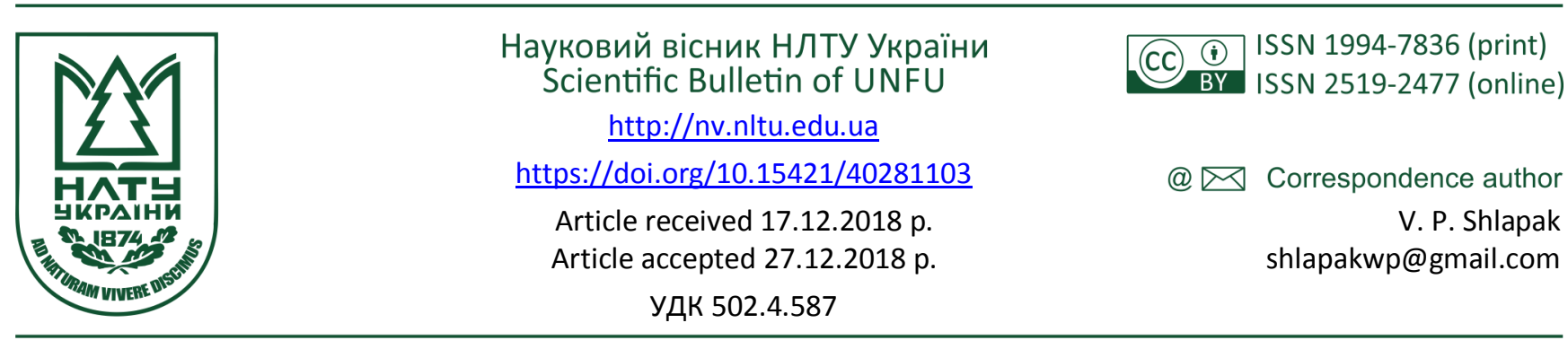

В. П. Шлапак', Н. П. Шиак ${ }^{1,2}$

${ }^{I}$ Уманський національний університет садівництва, м. Умань, Украӥна ${ }^{2}$ Наиіональний природний парк "Кармелюкове Поділля", смт Чечельник, Украӥна

\title{
КОМПЛЕКСНА ШКАЛА ОЦІНКИ ДЕКОРАТИВНОСТІ ВИДУ SORBUS TORMINALIS (L.) CRANTZ
}

\begin{abstract}
На основі літературних даних оцінки декоративності роду Sorbus L. (рід Горобина) і власних спостережень за декоративністю виду Sorbus torminalis (L.) Crantz (берека лікарська) розроблено комплексну шкалу оцінки декоративності цього виду. Sorbus torminalis L. - це аборигенний вид, компонент другого ярусу світлих широколистяних лісів, мезофіт, кальцефіл. Дерево до 25 м заввишки. Кора сірувато-коричнева, вздовж потріскана. Бруньки голі, округлояйцеподібної форми. Гарне блискуче листя має широкі лопаті. Квітки невеликі, зібрані у щитоподібні суцвіття. Плід яблуко червоно-коричневого забарвлення з білими крапками. Після аналізу декоративних, лікарських та харчових ознак в умовах Південно-Подільського Лісостепу України вид віднесено до високодекоративних дерев, належить до II групи деревних декоративних рослин. Під час оцінювання декоративності Sorbus torminalis, яка росте в лісових масивах Національного природного парку "Кармелюкове Поділля" та в населених пунктах Чечельницького району (Вінниччина), до уваги обрано такі декоративні ознаки: архітектоніку стовбура і крони, декоративність листків, суцвіть, квіток і плодів. Оцінювання проведено кожного місяця за п'ятибальною шкалою кожної ознаки. Результати подано у вигляді таблиць та графіку, які чітко демонструють зміну ступенів декоративності протягом року і дають змогу рекомендувати раритетний вид Sorbus torminalis для розширення асортименту зелених насаджень загального користування, що також буде сприяти збереженню та відновленню виду. Наведено морфологічний опис рослини та визначено цінні декоративні ознаки, які роблять тї перспективною для широкого використання в садовопарковому будівництві. Берека лікарська не тільки підвищить естетичні якості насаджень під час створення гармонійних ландшафтних композицій, але плоди, які мають унікальні лікарські властивості, можна використовувати для приготування різних харчових продуктів, а також їх охоче поїдають птахи, гризуни та інші тварини.
\end{abstract}

Ключові слова: Sorbus torminalis; ареал; декоративність; перевідний коефіцієнт; озеленення.

Вступ. Актуальним напрямом сучасного зеленого будівництва $\epsilon$ широке впровадження в озеленення населених пунктів малопоширених видів рослин. Під час їх використання пріоритетного значення набуває оцінка їх декоративності. До таких видів належить Sorbus torminalis (L.) Crantz (берека лікарська), представник роду Sorbus L. Ступінь вивчення виду досить низький, саму береку вже трохи забули. Сьогодні необхідно не просто зберегти береку, а виявити іiї великоплідні форми, які зникли в Західній Європі, а в Україні ще трапляються. Досліджено, що берека лікарська на східній і північносхідній межі ареалу стійкіша до екстремальних умов, тому ще збереглася в значній кількості в лісових масивах Бершадського, Чечельницького лісових господарствах, значно менше її в Тульчинському і Крижопільському.

Видова різноманітність та декоративність рослин роду Sorbus L. створюють широкі можливості для використання їх у зелених насадженнях міст і сіл. Горобинні ціняться не тільки за декоративність, а також як плодові та лікарські культури. Вид Sorbus torminalis (L.) Crantz (берека лікарська) обрано об'єктом дослідження 3 багатьох причин, а саме: іiї місцезростання приурочене до лісових екосистем, є однією з роду, яку найменше вико- ристовують в озелененні, занесено до Червоної книги України (2009р.) як зникаючий вид. Культивування раритетних видів рослин, з метою збереження їхнього генофонду, є одним із основних завдань сучасності, оскільки спричинені людиною зміни природних територій, їхня деградація внаслідок змін клімату, пришвидшують зникнення видів та популяцій (Bilyk \& Hryniuk, 2010; Bodnar, 2002; Budzhak, 1996; Hordiienko, Bondar \& Krynytskyi, 2006; Kotelova \& Grechko, 1969; Metodika, 1960; Metody otcenki, 1976; Misnik, 1976; Mudrak \& Mudrak, 2013; Ostapko, 2009; Riazanova \& Putenikhin, 2011; Syplyva, 2009).

Сьогодні існують різноманітні методики та шкали оцінки декоративності дерев і чагарників. Г. Е. Мисник (Mysnyk, 1964) вперше пропонує 7-бальну шкалу для оцінювання декоративності рослин на стадії їхнього цвітіння. Н. В. Котелова, Н. С. Гречко (Kotelova \& Grechko, 1969) розробили методику оцінювання декоративності, що передбачає застосування 4-бальної шкали, в основу якої покладено сприйняття рослини як елемента садової архітектури. Інша методика В. Н. Билова (Bylov, 1978) передбачає виділення ознаки декоративної цінності навіть під час оцінювання господарсько-біологічних особливостей сортів рослин. Н. В. Котелова

\section{Інформація про авторів:}

Шлапак Володимир Петрович, д-р с.-г. наук, професор, завідувач кафедри лісового господарства. Email: shlapakwp@gmail.com Шпак Ніна Петрівна, аспірант, кафедра лісового господарства. Email: spaknina0@gmail.com

Цитування за ДСту: Шлапак В. П., Шпак Н. П. Комплексна шкала оцінки декоративності виду Sorbus Torminalis (L.) Crantz. Науковий вісник НЛтУ України. 2018, т. 28, № 11. С. 18-23.

Citation APA: Shlapak, V. P., Shpak, N. P. (2018). The complex scale of decorative species of Sorbus Torminalis (L.) Crantz. Scientific Bulletin of UNFU, 28(11), 18-23. https://doi.org/10.15421/40281103 
та О. Н. Виноградова (Kotelova \& Vinogradova, 1974) розробили методику оцінювання декоративних ознак, за якою пропонують взяти за основу комплексний спосіб визначення декоративності деревних рослин. Автори пропонують оцінити декоративну цінність за сезонами, кожну декоративну ознаку оцінюють візуально за 5бальною шкалою, а для визначення вагомості окремої декоративної властивості встановлено перевідний коефіцієнт, виходячи із тривалості ії дії і сили емоційного впливу на людину (Kotelova \& Grechko, 1969; Litopys pryrody, 2015). Критеріями для оцінювання декоративності є: форма крони та листків; цвітіння; колір кори, листя, плодів. Інтегральну шкалу комплексного оцінювання декоративності для видів роду Sorbus L. пропонують Р. Г. Абдулліна та Н. О. Рязанова (Abdullina \& Riazanova, 2015). Питання щодо комплексної оцінки декоративності та стану насаджень парку в смт Макарів Київської обл. вивчили Н. В. Гатальська, Я. О. Лазаренко (Hatalska \& Lazarenko, 2012), а також їх висвітлено в працях А. І. Колесникова (Kolesnikov, 1974), Н. В. Котелової, Н. С. Гречко (Kotelova \& Grechko, 1969), С. А. Масловатої (Maslovata, 2015) та В. М. Остапка (Ostapko, 2009).

Мета дослідження - обстежити місця зростання i з'ясувати декоративні ознаки Sorbus torminalis для практичного використання в декоративному садівництві й озелененні.

Для розроблення наукових основ вирощування виду були поставлені такі завдання:

- визначити ступінь декоративності відповідно до розробленої шкали;

- охарактеризувати особливості сезонного розвитку в умовах Південно-Подільського Лісостепу України.

Об'скти і методи дослідження. Вид Sorbus torminalis належить до роду Sorbus L., якого вважають одним із кращих декоративних об'єктів, які висаджують біля садиб та використовують у зеленому будівництві. Рослини роду відрізняються різноманітністю крони, листя бувають прості та складні, які влітку мають різні відтінки зеленого, а восени вирізняються яскравим забарвленням від жовтих відтінків до яскраво-червоних на фоні будівель та інших дерев (Kotelova \& Grechko, 1969; Litopys pryrody, 2015).

У лісових масивах Національного природного парку "Кармелюкове Поділля" трапляються Sorbus torminalis. Це аборигенний вид, компонент другого ярусу світлих широколистяних лісів, мезофіт, кальцефіл. Дерево до 25 м заввишки. Кора сірувато-коричнева, вздовж потріскана. Бруньки голі, округлояйцеподібної форми. Гарне блискуче листя 16-18 см завдовжки і 5-10 см завширшки, має широкі лопаті. Квітки невеликі, 5-7 мм діаметром, зібрані у щитоподібні суцвіття. Оцвітина біла. Плід яблуко, 12-15 мм завдовжки та 8-12 мм діаметром, темно-коричневого або червоно-коричневого забарвлення з білими крапками. Щедра берека лікарська плодами, котрі можна використовувати для споживання. Це природні ліки від кишково-шлункових розладів. Плоди тверді та терпкі, але після перших заморозків вони стають м'якими, приємного смаку, желеподібної консистенції і нагадують смак кураги, багаті на різноманітні вітаміни та мінеральні речовини. Цвіте у квітнітравні, плодоносить у вересні-жовтні. Розмножується у природі насінням. За літературними даними, охоплює великі площі в Свропі, Передній Азії та Північній Аф- риці. В Україні проходить крайня північно-східна межа поширення виду: Закарпаття, Передкарпаття, Північна Бессарабія, Поділля. Окремі локалітети є в Гірському Криму (Bodnar, 2002; Budzhak, 1996).

Причиною зміни чисельності стало вирубування мішаних широколистяних лісів і заміна їх монокультурами, вибіркове рубання береки, як цінної деревини, для виготовлення меблів. Фахівці ландшафтного дизайну цінять береку за стрункість та незвичне листя, яке схоже на кленове. Охороняють Sorbus torminalis на теритоpiї ПЗ: Ялтинського гірсько-лісового, Карадазького, Кримського та "Медобори"; НПП "Подільські Товтри" та "Кармелюкове Поділля", РЛП "Чернівецький", "Дністровський каньйон"; у заповідних урочищах та пам'ятках природи Чернівецької, Івано-Франківської, Тернопільської та Вінницької областях. Заборонено вибіркові рубання дерев береки, руйнування місць зростання. Вирощують у багатьох ботанічних садах і дендропарках України.

У 1900 р. на всесвітній виставці у Парижі береку було визнано "Найкрасивішим деревом світу". 3 розвитком промислової індустрії почалися масові рубання береки через їі надміцну та красиву деревину. Це дерево занесли до Червоної книги майже 10 країн світу, в тому числі й Україна.

У 1983 р. на Вінниччині створено ботанічну пам'ятку природи місцевого значення - "Берека", яка розташована на території Петрашівської сільської ради (Петрашівське лісництво кв. 14 діл. 3) Ямпільського району. Охороняють один екземпляр береки (Sorbus torminalis) віком понад 100 років.

Результати досліджень та їх обговорення. Джерелами для наших досліджень були літературні відомості, зібрані за результатами їх критичного опрацювання, а також ми враховували результати власних польових досліджень, які проведені протягом 2014-2018 років. У практиці садівництва, під час оцінювання декоративності об'єктів, часто використовували шкали для красиво-квітучих рослин. Для декоративно-листяних рослин і разом із цим квітучих ці шкали не дають повної характеристики декоративності. Розроблення шкали оцінки декоративності видів, які рідко використовують в озеленені населених пунктів, $\epsilon$ пріоритетним завданням НПП "Кармелюкове Поділля". Під час розроблення шкали за основу взяли принцип бальної оцінки декоративності з використанням перевідного коефіцієнта. Для загального оцінювання декоративності виду Sorbus torminalis використали методику Н. В. Котелової та О. Н. Виноградової у модифікації І. В. Таран і А. М. Агапової (Kotelova \& Vinogradova, 1974), що містить таку шкалу декоративності: 1) декоративність негативна (зовнішній вигляд рослин не створює привабливості); 2) нульова (декоративні властивості не виражені або рослини не мають виразності на загальному фоні насаджень); 3) незначна (декоративні властивості помітні, але не надто виразні); 4) достатня (декоративні властивості виразні, рослини добре виділяються на загальному фоні насаджень); 5) висока (декоративні властивості надають рослинам значної привабливості, зумовлюють у масового спостерігача сильне емоційне відчуття, захоплення). Згідно з цим підходом, елементами, які визначають декоративну цінність, $\epsilon$ :

- $a_{1}$ - архітектоніка стовбура та крони (перевідний коефіцієнт $\left.P_{1}=4\right)$; 
- $a_{2}$ - листя рослин $\left(P_{2}=3\right)$;

- $a_{3}$ - декоративність суцвіття, квітів і плодів $\left(P_{3}=2\right)$;

- $a_{4}$ - колір і фактура кори стовбура та пагонів $\left(P_{4}=1\right)$.

Якщо $a_{1}, a_{2}, a_{3}, a_{4}$ - бали оцінки за кожною 3 виділених ознак, то загальна оцінка декоративності виражається через величини значення $D$, розрахованого за формулою (табл. 1)

$$
D=\frac{\sum_{i=1}^{4} P_{i} \cdot a_{i}}{\sum_{i=1}^{4} P_{i}} .
$$

Табл. 1. Визначення загальної декоративності Sorbus torminalis

\begin{tabular}{|c|c|c|c|}
\hline $\begin{array}{c}\text { Архітектоніка } \\
\text { стовбура та } \\
\text { крони }\end{array}$ & $\begin{array}{c}\text { Листя } \\
\text { рослин }\end{array}$ & $\begin{array}{c}\text { Декоративність } \\
\text { суцвіття, квітів і } \\
\text { плодів }\end{array}$ & $\begin{array}{c}\text { Колір і фактура } \\
\text { кори стовбура та } \\
\text { пагонів }\end{array}$ \\
\hline $4 \times 4$ & $5 \times 3$ & $4 \times 2$ & $2 \times 1$ \\
\hline
\end{tabular}

$$
D=\frac{16+15+8+2}{4+3+2+1}=4,1 \text { бала. }
$$

Для визначення ступеня декоративності ми скористалися такою шкалою:

- 1 - декоративність слабка (менше 2 бали);

- 2 - декоративність посередня (2,1-3 бали);

- 3 - декоративність достатня (3,1-4 бали);

- 4 - декоративність висока (4,1-5 балів).

Згідно з цією шкалою, Sorbus torminalis можна віднести до дендросозоекзотів із високою декоративністю.

Використавши методику О. Г. Хороших і О. В. Хороших (Khoroshykh \& Khoroshykh, 1999), які деталізують цю методику, ми розробили шкалу (табл. 2), яка включає 12 основних ознак декоративності виду: період декоративності, забарвлення кори, форма крони, декоративність квітів і плодів, терміни опадання плодів, форма листка, літнє забарвлення листків, осіннє забарвлення листків, період осіннього забарвлення листків, оригінальність рослини, зимостійкість, естетичні властивості ландшафтів з участю береки. Перевідні коефіцієнти визначають значущість ознаки в сумарній оцінці декоративності (Kalinichenko, 2003; Kolesnikov, 1974; Frolova, 1994; Khoroshykh \& Khoroshykh, 1999).

Період декоративності. Відповідно до рекомендацій Н. А. Рязанова, В. П. Путенихіна (Riazanova \& Putenikhin, 2011), виділено такі періоди: декоративність протягом усього календарного року (вічнозелені рослини), вегетаційного сезону та певного періоду вегетації (включає переважно декоративно-листяні, квітучі та плодово-декоративні рослини). Використали три градації оцінки залежно від періоду декоративності протягом року (див. табл. 2).

Забарвлення кори. Берека не відзначається високою декоративністю кори.

Форма крони. Крона (форма, структура, облиствлення). Під час оцінювання за цими ознаками враховано вікову декоративність залежно від архітектоніки крони. Для береки ми змінили процент облиствлення крони, що пов'язано з ії високою щільністю. Розподіл рослин за висотою проводили за рекомендаціями О. А. Калініченка (Kalinichenko, 2003; Koldar \& Shlapak, 2002).

Декоративність квітів. За основу взяли шкалу Г. Е. Мисника (Mysnyk, 1964; Misnik, 1976). Виключили залежність оцінки декоративності від емоційного стану людини в цей період. Врахували декоративні властивості квітів: розміри, суцвіття, форма, забарвлення, запах, тривалість і рясність цвітіння.
За методикою Н. А. Коляди, як висвітлив у своїй роботі Г. Е. Мисник (Misnik, 1976), декоративність плодів визначали за зміною забарвлення у період дозрівання, кількістю плодів, періодом максимальної декоративності. Враховували особливості квітування та плодоношення, які розглянуто у праці В. П. Шлапака, В. В. Мамчур, О. М. Баюри, Н. П. Шпак, В. В. Шлапака, О. Ю. МарноКуца (Shlapak et al., 2018).

Терміни опадання плодів. Період дозрівання плодів береки лікарської довготривалий (1,5 місяця): починається у другій декаді серпня і триває до кінця вересня. Плоди залишаються на дереві до перших заморозків, а потім поступово опадають, спочатку недозрілі або пошкоджені, пізніше - якісні. Частина плодів у лісових масивах може залишатися на верхівках дерев до сильних морозів. За фенологічними спостереженнями видів роду Cersis L., Л. А. Колдар, В. П. Шлапак (Koldar \& Shlapak, 2002) додатково виділили фенологічну фазу природного зберігання насіння в бобах безпосередньо на деревах взимку. Ця ж фенологічна фаза притаманна збереженню насіння у плодах Sorbus torminalis. Водночас терміни опадання плодів залежить від кліматичних умов регіону.

Форма листка. Берека відзначається оригінальним простим блискучим листям, схожим до кленового, збіжистої форми з 5-7 лопатями. За цією ознакою виділили п'ять градацій.

Літнє забарвлення листків. Для оцінювання літнього забарвлення листків використали пропозиції Н. А. Рязанової та В. П. Путенихіна (Riazanova \& Putenikhin, 2011). Ознаку диференціювали залежно від різноманітності відтінків кольорів. Вищий бал - у рослин 3 кольоровими листками, нижчий - 3 однотонним зеленим забарвленням.

Осіннє забарвлення листків. Це важлива ознака декоративності для береки лікарської. Зміна забарвлення проходить у декілька етапів, що варто враховувати під час створення ландшафтних композицій.

Період осіннього забарвлення листків залежить від температури повітря в осінній період. Якщо тепла осінь, то листя на деревах залишається до 20 днів яскраво-жовтого забарвлення, потім стає оранжевим, а пізніше червоним. Берека вирізняється на фоні забарвлень листя інших деревних рослин, окрім кленів і айланта (Riazanova \& Putenikhin, 2011; Frolova, 1994).

Оригінальність рослин визначали згідно з "Методикою державного сортовипробування" (Bylov, 1978; Metodika, 1960). Показники підкреслюють специфічність комплексу ознак: форма крони і листкової пластинки, зміна забарвлення листя і плодів, рясність цвітіння та ін.

Зимостійкість - це властивість рослин витримувати без пошкоджень комплекс умов перезимівлі (тріскучі морози, різкі відлиги, значні перепади від тепла до холоднечі) (Kolisnichenko, 2004). Найбільшу небезпеку для береки становлять: низькі критичні температури в січні та лютому, кількість опадів чи наявність посух, тривалість вегетаційного періоду вологозабезпеченість грунтів й інші природні чинники, які не $є$ постійними за роками. Польову зимостійкість оцінювали візуально за 8-бальною шкалою С. Я. Соколова (Sokolov, 1957): pocлина зимує без пошкоджень (1 бал); підмерзає верхівка річних пагонів (2 бали); підмерзають різні пагони (3 бали); підмерзають гілки останніх двох років (4 бали); 
підмерзають гілки останніх трьох років (5 балів); підмерзає стовбур до рівня снігового покриву (6 балів); підмерзає стовбур до кореневої шийки, проте рослина утворює поросль (7 балів); рослина гине від морозу (8 балів).

Згідно 3 результатами польових досліджень, вид добре пристосований до комплексу природних чинників у зимовий період (середня оцінка - 2,5 бала). Такі пошкодження майже не позначаються на подальшому розвитку береки лікарської. У разі пошкодження максимально низькими температурами, рослини здатні до відновлення пагонової системи. Несподівані морози (5$\left.6{ }^{\circ} \mathrm{C}\right)$ в березні стають причиною зменшення плодоношення береки. Кожна лісова ділянка має свої нюанси, які впливають на стан рослини. Тому бальний метод дає лише загальну характеристику про морозо- та зимостійкість рослини.

Табл. 2. Шкала градацій ознак для оцінки декоративності виду Sorbus torminalis L.

\begin{tabular}{|c|c|c|c|c|c|c|}
\hline \multirow{2}{*}{ Ознака } & \multicolumn{5}{|c|}{ Бал } & $\Pi_{\kappa}$ \\
\hline & 1 & 2 & 3 & 4 & 5 & \\
\hline $\begin{array}{c}\text { Період } \\
\text { декоративності }\end{array}$ & & & $\begin{array}{c}\text { певний період } \\
\text { вегетації }\end{array}$ & вегетаційний сезон & $\begin{array}{c}\text { протягом усього } \\
\text { року }\end{array}$ & 3 \\
\hline $\begin{array}{c}\text { Забарвлення } \\
\text { кори }\end{array}$ & $\begin{array}{l}\text { кора чорна, } \\
\text { темно-сіра }\end{array}$ & сіра, коричнева, бура & $\begin{array}{c}\text { світло-сіра, } \\
\text { світло-коричнева }\end{array}$ & $\begin{array}{c}\text { кольорова } \\
\text { (біла, жовта, } \\
\text { червона, зелена) }\end{array}$ & $\begin{array}{l}\text { кора і пагони } \\
\text { різнокольорові }\end{array}$ & 1 \\
\hline $\begin{array}{l}\text { Крона (форма, } \\
\text { структура, } \\
\text { облиствлення) }\end{array}$ & $\begin{array}{c}\text { не сформована, } \\
\text { облиствлення } \\
\text { менше } 30 \%\end{array}$ & $\begin{array}{c}\text { рідка, неоднорідна, } \\
\text { облиствлення 31-60\% }\end{array}$ & $\begin{array}{c}\text { рідка, слабо } \\
\text { однорідна, об- } \\
\text { листвлення } 61-70 \%\end{array}$ & $\begin{array}{c}\text { середньо-щільна, } \\
\text { середньо-однорідна, } \\
\text { облиствлення 71- } \\
80 \%\end{array}$ & $\begin{array}{c}\text { щільна, однорідна, } \\
\text { облиствлення до } \\
100 \%\end{array}$ & 2 \\
\hline $\begin{array}{c}\text { Декоративність } \\
\text { квітів і плодів }\end{array}$ & $\begin{array}{c}\text { квіти і плоди } \\
\text { знижують деко- } \\
\text { ративний ефект }\end{array}$ & практично не помітні & $\begin{array}{c}\text { помітні, але не } \\
\text { підсилюють } \\
\text { декоративний ефект }\end{array}$ & $\begin{array}{c}\text { квіти і плоди добре } \\
\text { помітні, підсилю- } \\
\text { ють декоративний } \\
\text { ефект }\end{array}$ & $\begin{array}{c}\text { квіти і плоди чітко } \\
\text { виділяються на фоні } \\
\text { листя }\end{array}$ & 1 \\
\hline $\begin{array}{l}\text { Терміни опа- } \\
\text { дання плодів }\end{array}$ & $\begin{array}{c}\text { плоди опадають } \\
\text { зразу після } \\
\text { дозрівання } \\
\end{array}$ & $\begin{array}{c}\text { плоди утримуються на } \\
\text { гілках до місяця }\end{array}$ & \begin{tabular}{|c} 
плоди утримуються \\
на гілках від 1 до \\
2 місяців \\
\end{tabular} & \begin{tabular}{|c|} 
плоди утримуються \\
на гілках від 2 до \\
3 місяців \\
\end{tabular} & $\begin{array}{c}\text { плоди утримуються } \\
\text { на гілках більше } \\
3 \text { місяців } \\
\end{array}$ & 1 \\
\hline Форма листка & $\begin{array}{c}\text { листки прості } \\
\text { або складні з 3- } \\
5 \text { листочками }\end{array}$ & $\begin{array}{c}\text { листки прості з лопа- } \\
\text { теподібними зубцями, } \\
\text { лопаті не доходять до } \\
\text { середини пластинки; } \\
\text { складні - } 5 \text {-7 лис- } \\
\text { точками } \\
\end{array}$ & $\begin{array}{c}\text { листки прості з зуб- } \\
\text { цями або лопатями, } \\
\text { які доходять до сере- } \\
\text { дини пластинки }\end{array}$ & $\mid \begin{array}{c}\text { листки прості, лопа- } \\
\text { ті доходять майже } \\
\text { до середини листко- } \\
\text { вої пластинки }\end{array}$ & \begin{tabular}{|c|} 
листки прості, розсі- \\
чені, лопаті доходять \\
до середини листко- \\
вої пластинки, перша \\
пара майже до цен- \\
тральної жилки \\
\end{tabular} & 2 \\
\hline $\begin{array}{c}\text { Літнє } \\
\text { забарвлення } \\
\text { листків }\end{array}$ & $\begin{array}{c}\text { листки зелені, } \\
\text { з обох боків } \\
\text { однорідні }\end{array}$ & $\begin{array}{c}\text { різнокольорові - вер- } \\
\text { хня і нижня сторони } \\
\text { листкової пластинки } \\
\text { мають різне забар- } \\
\text { влення }\end{array}$ & $\begin{array}{c}\text { плямисті - мають } \\
\text { різного забарвлення } \\
\text { i форми плями на зе- } \\
\text { леному фоні }\end{array}$ & $\begin{array}{c}3 \text { каймою по краю } \\
\text { листка іншого } \\
\text { забарвлення }\end{array}$ & $\begin{array}{c}\text { кольорові - листкова } \\
\text { пластинка з обох } \\
\text { боків різного } \\
\text { забарвлення, окрім } \\
\text { зеленого }\end{array}$ & 2 \\
\hline $\begin{array}{c}\text { Осіннє забар- } \\
\text { влення листків }\end{array}$ & $\begin{array}{c}\text { листки залиша- } \\
\text { ються зеленими } \\
\end{array}$ & $\begin{array}{c}\text { переважає жовте } \\
\text { забарвлення } \\
\end{array}$ & $\begin{array}{c}\text { переважає оранжеве } \\
\text { забарвлення } \\
\end{array}$ & $\begin{array}{c}\text { переважає червоне } \\
\text { забарвлення } \\
\end{array}$ & \begin{tabular}{|c|} 
переважає пурпурове \\
забарвлення \\
\end{tabular} & 2 \\
\hline $\begin{array}{c}\text { Період осінньо- } \\
\text { го забарвлення } \\
\text { листків } \\
\end{array}$ & менше 15 днів & 16-23 дня & 24-31 день & 32-39 днів & більше 39 днів & 3 \\
\hline $\begin{array}{c}\text { Оригінальність } \\
\text { рослини }\end{array}$ & звичайна & слабка & середня & висока & дуже висока & 2 \\
\hline Зимостійкість & VII балів & V-VI балів & IV бала & II-III бали & I бал & 1 \\
\hline $\begin{array}{c}\text { Естетичні влас- } \\
\text { тивості лан- } \\
\text { дшафтів з учас- } \\
\text { тю береки } \\
\end{array}$ & $\begin{array}{c}\text { гармонія при- } \\
\text { родних і антро- } \\
\text { погенних } \\
\text { об'єктів }\end{array}$ & $\begin{array}{c}\text { наявність живописних } \\
\text { урочищ, де приємно } \\
\text { відпочивати }\end{array}$ & $\begin{array}{c}\text { наявність пам'ятни- } \\
\text { ків вікових дерев, } \\
\text { красиві антропогенні } \\
\text { об'єкти }\end{array}$ & \begin{tabular}{|c|} 
наявність оглядових \\
площадок, з яких \\
відкривається кра- \\
сивий краєвид
\end{tabular} & $\begin{array}{c}\text { виразність рельєфу } \\
\text { місцевості }\end{array}$ & 2 \\
\hline
\end{tabular}

Примітка: Пк - перевідний коефіцієнт.

Естетичні властивості ландшафтів. Рослини оцінювали за шкалою В. А. Фролової (Frolova, 1994). Оцінку естетичного стану деревних рослин проводили за модифікованою шкалою В. П. Шлапака, Г. І. Музики, В. А. Вітенко, Л. І. Марно, Н. О. Гончар (Shlapak et al., 2010b), а розподіл деревних рослин за віковими категоріями здійснювали за розробленою 3-бальною шкалою та згодом модифікованою В. П. Шлапаком, Г. І. Музикою, В. А. Вітенком, Л. I. Марно (Shlapak et al., 2010а) у 4-бальну, ввівши категорію потенційно вікові.

Відповідно до запропонованої шкали декоративності, виділяємо ознаки для Sorbus torminalis і враховуємо перевідний коефіцієнт. Обраховуємо сумарну кількість балів, визначаємо ступінь оцінки декоративності (див. табл. 2 і 3). Визначили сумарну кількість балів для береки лікарської - 64 бали. Належить до II групи декоративності листопадних дерев (див. табл. 3). Вивчення динаміки сезонного розвитку рослин необхідне для оцінювання естетичних і санітарно-гігієнічних властивостей цих порід упродовж року.

Табл. 3. Ступені оцінки декоративності дерев і чагарників

\begin{tabular}{|c|c|c|c|c|}
\hline $\begin{array}{c}\text { Ступінь де- } \\
\text { коративнос- } \\
\text { ті в балах }\end{array}$ & $\begin{array}{c}\text { декоратив- } \\
\text { ність низь- } \\
\text { ка }\end{array}$ & $\begin{array}{c}\text { декоратив- } \\
\text { ність се- } \\
\text { редня }\end{array}$ & $\begin{array}{c}\text { декоратив- } \\
\text { ність висо- } \\
\text { ка }\end{array}$ & $\begin{array}{c}\text { декоратив- } \\
\text { ність дуже } \\
\text { висока }\end{array}$ \\
\hline $\begin{array}{c}\text { Група деко- } \\
\text { ративності }\end{array}$ & IV & III & II & I \\
\hline
\end{tabular}

Декоративну цінність представників роду визначали під час фенологічних спостережень на території НПП 
"Кармелюкове Поділля". За методикою Н. В. Котелової та О. Н. Виноградової (Kotelova \& Vinogradova, 1974) побудували графік порівняння динаміки зміни сезонної декоративності береки лікарської протягом року. Декоративність оцінювали за п'ятибальною шкалою (рисунок). Оскільки вид роду Sorbus L. листопадний, то в період безлистого стану архітектоніку стовбура і крони оцінили в 13 балів.

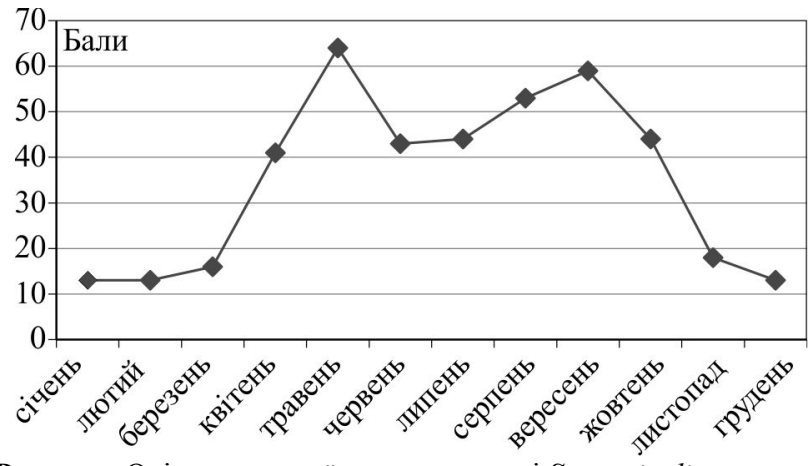

Рисунок. Оцінка сезонної декоративності S. torminalis

\section{Висновки:}

1. На основі власних досліджень із застосуванням інтегровано-аналітичного підходу розроблено якісно нову шкалу комплексної оцінки декоративності для раритетного виду Sorbus torminalis.

2. Амплітуда оцінки декоративності виду Sorbus torminalis змінюється від 13 до 64 балів. Найбільш декоративним вид $є$ від середини квітня до середини листопаду. Найменш декоративним - взимку.

3. За ступенем декоративності виду Sorbus torminalis висвітлили його оригінальність для використання у ландшафтному будівництві та фітодизайні.

4. Sorbus torminalis належить до високодекоративних дерев, має II групу декоративності, $є$ перспективною для декоративного озеленення, що сприятиме збереженню та відновленню раритетного виду.

\section{Перелік використаних джерел}

Abdullina, R. G., \& Riazanova, N. A. (2015). Metodika otcenki dekorativnosti vidov i sortov roda Sorbus L. Izvestiia Samarskogo nauchnogo tcentra, 17(4), 240-244. [In Russian].

Bilyk, Ya. Ya., \& Hryniuk, Yu. H. (2010). Fenolohichni sposterezhennia na obiektakh pryrodno-zapovidnoho fondu yak skladova monitorynhu klimatychnykh zmin. Pryrodno-zapovidnyi fond Ukrainy - mynule, sohodennia, maibutnie: mater. Mizhnar. nauk.prakt. konf., (pp. 237-241). Ternopol, May 26-28. [In Ukrainian].

Bodnar, A. O. (2002). Bereka v lisovykh nasadzhenniakh. Vinnytsia, 64 p. [In Ukrainian].

Budzhak, V. V. (1996). Bereka (Sorbus torminalis (L.) Crantz) u pivnichnii Bukovyni ta pivnichnii Bessarabii (khronolohiia, bioekolohiia, okhorona). Candidate dissertation for biology sciences. Chernivtsi, 293 p. [In Ukrainian].

Bylov, V. N. (1978). Osnovy sravnitelnoi sortootcenki dekorativnikh rastenii, (pp. 7-31). Moscow: Nauka, 360 p. [In Russian].

Frolova, V. A. (1994). Otcenka esteticheskikh dostoinstv prirodnykh landshaftov. (Ser. Geografiia). Vestnik $M G U, 5(2), 27-33$. [In Russian].

Hatalska, N. V., \& Lazarenko, Ya. O. (2012). Kompleksna otsinka dekoratyvnosti ta stanu nasadzhen parku u smt Makariv Kyivskoi oblasti. Scientific reports of the National University of Bioresources and Natural Resources of Ukraine. Series: Arboriculture and Ornamental Horticulture, 171(2), 229-233. [In Ukrainian].

Hordiienko, M. I. (Ed.), Bondar, A. O., \& Krynytskyi, H. T. (2006). Lisovi nasadzhennia Vinnychchyny. Kyiv: Urozhai, 248 p. [In Ukrainian].
Kalinichenko, O. A. (2003). Dekoratyvna dendrolohiia. Kyiv: Vyshcha shkola, 199 p. [In Ukrainian].

Khoroshykh, O. H., \& Khoroshykh, O. V. (1999). Shkala kompleksnoi otsinky dekoratyvnykh oznak derevnykh roslyn. Scientific Bulletin of UkrDLTU. Series: Exploration, Protection and Enrichment of Biodiversity, 9(9), 167-170. [In Ukrainian].

Koldar, L. A., \& Shlapak, V. P. (2002). Biolohichni osoblyvosti diahnostyky fenolohichnykh faz u Cercis Canadensis L. v umovakh dendroparku "Sofiivka" NAN Ukrainy. Scientific herald of Chernivtsi University. Series: Biology, 144, 179-184. [In Ukrainian].

Kolesnikov, A. I. (1974). Dekorativnaia dendrologiia. Moscow: Lesnaia prom-st, 704 p. [In Russian].

Kolisnichenko, O. M. (2004). Sezonni biorytmy ta zymostiikist derevnykh roslyn. Kyiv: Fitosotsiotsentr, 176 p. [In Ukrainian].

Kotelova, N. V., \& Grechko, N. S. (1969). Otcenka dekorativnosti. Tcvetovodstvo, 10, 11-12. [In Russian].

Kotelova, N. V., \& Vinogradova, O. N. (1974). Otcenka dekorativnosti derevev $i$ kustarnikov po sezonam goda. Fiziologiia $i$ selektciia rastenii i ozelenenie gorodov, (pp. 37-44). Moscow: MLTI, 344 p. [In Russian].

Litopys pryrody. (2015). NPP "Karmeliukove Podillia". (Vol. 3), 261 p. [In Ukrainian].

Maslovata, S. A. (2015). Otsinka dekoratyvnosti rodu Ulmus L. ta yikh form u Pravoberezhnomu Lisostepu. Naukovi dopovidi NUBIP Ukrainy, 6(55), 22. [In Ukrainian].

Metodika. (1960). Metodika gosudarstvennogo sortoispytaniia dekorativnykh kultur. Moscow: Izdatelstvo selskogo khoziaistva RSFSR, 182 p. [In Russian].

Metody otcenki. (1976). Metody otcenki ustoichivosti rastenii k neblagopriiatnym usloviiam sredy. Leningrad: Kolos, 318 p. [In Russian].

Misnik, G. E. (1976). Sroki, kharakter tcveteniia derevev i kustarnikov. Kyiv: Naukova dumka, 392 p. [In Russian].

Mudrak, O. V., \& Mudrak, H. V. (2013). Osoblyvosti zberezhennia bioriznomanittia Podillia: teoriia i praktyka. Vinnytsia: TOV "Nilan LTD", 320 p. [In Ukrainian].

Mysnyk, H. E. (1964). Do otsinky dekoratyvnosti derev ta chaharnykiv u fazakh yikh tsvitinnia ta plodonoshennia. Biolohiia i kultura derevnykh ta chaharnykovykh roslyn, (pp. 100-101). Kyiv: Nauk. dumka, 280 p. [In Ukrainian].

Ostapko, V. M. (2009). Shkala otcenki dekorativnosti petrofitnykh vidov flory iugo-vostoka Ukrainy. Introduktciia rastenii, 1, 18-22. [In Russian].

Riazanova, N. A., \& Putenikhin, V. P. (2011). Otcenka dekorativnosti klenov v Ufimskom Botanicheskom sadu. Vestnik IrGSKhA, 4(44), 121-128. [In Russian].

Shlapak, V. P., Mamchur, V. V., Baiura, O. M., Shpak, N. P., Shlapak, V. V., \& Marno-Kutsa, O. Yu. (2018). Osoblyvosti kvituvannia ta plodonoshennia Ailanthus altissima v umovakh Pravoberezhnoho Lisostepu i Stepu Ukrainy. Scientific Bulletin of UNFU, 28(8), 20-30. [In Ukrainian].

Shlapak, V. P., Muzyka, H. I., Vitenko, V. A., \& Marno, L. I. (2010a). Vikovi derevni roslyny Natsionalnoho dendroparku "Sofiivka" NAN Ukrainy ta shliakhy yikh zberezhennia. Istoriia zaporizkoho kozatstva $v$ pamiatkakh ta muzeinii praktytsi: mater. IV Mizhnar. nauk.-prakt. konf., (pp. 364-366). Zaporizhzhia: Khortytsia. [In Ukrainian].

Shlapak, V. P., Muzyka, H. I., Vitenko, V. A., Marno, L. I., \& Honchar, N. O. (2010b). Metody otsinky estetychnoho stanu vikovykh derevnykh nasadzhen istorychnoi chastyny natsionalnoho dendroparku "Sofiivka" NAN Ukrainy. Scientific Bulletin of UNFU, 20(6), 8-13. [In Ukrainian].

Sokolov, S. Ia. (1957). Sovremennoe sostoianie teorii i introduktcii rastenii. Introduktciia rastenii i zelenoe stroitelstvo. Trudy Botanicheskogo instituta AN SSSR, 6, 34-42. [In Russian].

Syplyva, N. O. (2009). Strukturnyi analiz rarytetnoi dendroflory Vinnytskoi oblasti. Scientific Bulletin of UNFU, 19(5), 39-42. [In Ukrainian]. 


\title{
КОМПЛЕКСНАЯ ШКАЛА ОЦЕНКИ ДЕКОРАТИВНОСТИ ВИДА SORBUS TORMINALIS (L.) CRANTZ
}

На основе литературных данных оценки декоративности рода Sorbus L. (род Рябина) и собственных наблюдений за декоративными качествами Sorbus torminalis (L.) Crantz (берека лекарственная) разработана комплексная шкала, дающая возможность комплексно оценить степень декоративности данного вида. Sorbus torminalis L. - это аборигенный вид, компонент второго яруса светлых широколиственных лесов, мезофит, кальцефил. Дерево до 25 м высотой. Кора серовато-коричневая, вдольпотрескавшаяся. Почки голые, округлой формы. Блестящие листья имеют широкие лопасти. Цветки небольшие, собраны в щитовидное соцветия. Плод яблоко красно-коричневого окраса с белыми точками. Учтены декоративные, лечебные и пищевые качества вида в условиях Южно-Подольской Лесостепи Украины. В итоге вид отнесен к высокодекоративным древесным растениям и принадлежит ко II группе декоративности. Для оценки декоративности Sorbus torminalis, которая растет в лесных насаждениях Национального природного парка "Кармелюковое Подолье" и изредка в населенных пунктах Чечельницького района (Винницкая область) выбраны следующие декоративные признаки: архитектоника ствола и кроны, декоративность листьев, цветков и соцветий, плодов. Оценка проводилась ежемесячно по двенадцати критериям по 5-балльной шкале. По результатам оценки выстраивается график, на котором хорошо видна изменчивость степени декоративности вида в течение года. Суммирование ежемесячных оценок степени декоративности дает общую годовую оценку, которая может использоваться при сравнении общей степени декоративности видов, форм и сортов между собой. Это позволяет рекомендовать вид Sorbus torminalis для расширения ассортимента зеленых насаждений общего пользования, которые также будут способствовать сохранению и возобновлению исчезающего вида. В результате морфологического описания растения определена совокупность внешних признаков, которые делают его перспективным для использования в садово-парковом строительстве. Sorbus torminalis не только повысит эстетические качества ландшафтных композиций, но и плоды, которые имеют уникальные лечебные свойства, можно использовать для приготовления различных пищевых продуктов, а также ими кормятся, в зимний период, птицы, грызуны и других животные.

Ключевые слова: Sorbus torminalis; ареал; декоративность; переводной коэффициент; озеленение.

\author{
V. P. Shlapak1, N. P. Shpak ${ }^{1,2}$ \\ ${ }^{1}$ Uman National University of Horticulture, Uman, Ukraine \\ 2 National Park "Karmelyukove Podillya", Chechelnik, Ukraine
}

THE COMPLEX SCALE OF DECORATIVE SPECIES OF SORBUS TORMINALIS (L.) CRANTZ

Based on the literature data for evaluating the ornamentation of the genus Sorbus L. (the Ryabina genus) and its own observations of the decorative qualities of the Sorbus torminalis (L.) Crantz, a complex scale is developed, enabling comprehensive assessment of the degree of decorativeness of this species. Sorbus torminalis L. is a native species, a component of the second tier of light deciduous forests, mesophyte, calcephil. The tree is up to $25 \mathrm{~m}$ tall. The bark is greyish-brown, cracked along the trunk. The buds are bare, round shape. Brilliant leaves have wide lobes. The flowers are small, gathered in thyroid inflorescence. The fruit of the Apple is red-brown colour with white dots. Its decorative, medical and nutritional qualities are taken into account in the conditions of the South Podolsk Forest-Steppe of Ukraine. As a result, the species is classified as a highly decorative woody plant and belongs to the second group of decorativeness. To evaluate the decorativeness of Sorbus torminalis L., which grows in the forest stands of the National Natural Park "Karmeliukove Podillya" and occasionally in the settlements of Chechelnitsky District (Vinnytsia Region), the following decorative features are chosen: architectonics of the trunk and crown, decorative leaves, flowers and inflorescences, fruits. The evaluation was carried out monthly for twelve criteria on a five-point scale. According to the results of the assessment, a graph is drawn up, on which the variability of the degree of decorativeness of the species during the year is clearly visible. Summing up the monthly estimates of the degree of decorativeness gives a total annual estimate that can be used when comparing the overall degree of decorativeness of the species, forms and varieties among them. This allows us to recommend the Sorbus torminalis species for expanding the range of public green spaces, which will also contribute to the preservation and renewal of the endangered species. As a result of the morphological description of the plant, they determined a set of external features that make it promising for use in landscape gardening. Sorbus torminalis will not only enhance the aesthetic qualities of landscape compositions, but also fruits that have unique healing properties can be used to prepare food, as well as feed birds, rodents, and other animals in winter.

Keywords: Sorbus torminalis; areal; decorative; conversion factor; gardening. 